\title{
MARGINALISASI KESEJAHTERAAN HEWAN AKIBAT AMBISI PENINGKATAN EKSPOR MINYAK SAWIT DI INDONESIA
}

\section{MARGINALIZATION OF ANIMAL WELFARE DUE TO AMBITION TO INCREASE EXPORT OF PALM OIL IN INDONESIA}

\author{
Anggalih Bayu Muh. Kamim a dan Muhammad Irsyad Abrar ${ }^{\text {b }}$ \\ a Alumnus Departemen Politik \& Pemerintahan, Fakultas IImu Sosial \& IImu \\ Politik, Universitas Gadjah Mada \\ ${ }^{b}$ Departemen Hubungan Internasional, Fakultas IImu Sosial \& IImu Politik, \\ Universitas Gadjah Mada \\ JI. Sosio Yustisia, Caturtunggal, Kec. Depok, Kabupaten Sleman, Daerah \\ Istimewa Yogyakarta 55281, \\ Email: anggalih.bayu@yahoo.co.id; muhammad.irsyad.abrar@gmail.com;
}

Naskah diterima: 11 Desember 2019; revisi terakhir: 18 Februari 2020; disetujui 12 Maret 2020

How to Cite: Kamim, Anggalih Bayu Muh., dan Abrar, Muhammad Irsyad. (2020). Marginalisasi Kesejahteraan Hewan Akibat Ambisi Peningkatan Ekspor Minyak Sawit di Indonesia. Jurnal Borneo Administrator, 16 (1), 39-60. https://doi.org/10.24258/jba.v16i1.641

\begin{abstract}
The Indonesia Government has taken various measures to counter the European Union's policies which are considered will harmful the efforts to increase palm oil exports. However, the efforts of the Indonesian government to maintain the image of the palm oil commodity considered a hiding act from animal and human conflicts. One of which arises from the expansion of oil palm plantations. This study would explore the outbreak of animal and human conflicts affected by the expansion of oil palm plantations due to the ambition of increasing palm oil export. This research was a desk study conducted by tracing various journal articles, reports of oil palm plantation guard organizations, reports of civil society organizations related to deforestation of oil palm expansion and various reports of civil society organizations about cases between animal and human conflict. The results of the study showed that there had been a misunderstanding in understanding the European Union's decision, which would not impact on the decline in palm oil exports. Sustainable palm oil governance is not well implemented by oil palm companies and the Indonesian Government so that marginalizing animal life. The intensity of animal-human conflict continues to occur in various areas of oil palm concessions that lead to the threat wild animal life.
\end{abstract}

Keywords: Palm Oil Exports, Animal-Human Conflict, Animal Welfare 


\begin{abstract}
Abstrak
Pemerintah Indonesia melakukan berbagai cara untuk mengkonter kebijakan Uni Eropa yang dianggap akan merugikan upaya peningkatan ekspor kelapa sawit. Akan tetapi, upaya pemerintah Indonesia menjaga citra komoditas minyak kelapa sawit seolah menutupi permasalahan konflik satwa dan manusia yang salah satunya muncul akibat ekspansi perkebunan sawit. Kajian ini akan mendalami merebaknya konflik satwa dan manusia yang terdampak ekspansi perkebunan sawit akibat ambisi peningkatan ekspor crude palm oil. Penelitian ini adalah desk study yang dilakukan dengan melakukan penelusuran terhadap berbagai artikel jurnal, laporan organisasi pengawal perkebunan sawit, laporan organisasi masyarakat sipil yang terkait dengan deforestasi akibat ekspansi sawit, dan berbagai laporan organisasi masyarakat sipil mengenai kasus konflik antara satwa dan manusia. Hasil kajian menunjukan bahwa telah terjadi kesalahpahaman dalam memahami keputusan Uni Eropa yang sama sekali tidak akan berdampak pada berkurangnya ekspor minyak kelapa sawit. Tata kelola sawit berkelanjutan tidak dilaksanakan dengan baik oleh perusahaan sawit dan Pemerintah Indonesia, sehingga meminggirkan peri kehidupan hewan. Intensitas konflik satwamanusia terus terjadi di berbagai wilayah konsesi sawit yang berujung pada keterancaman peri kehidupan binatang liar
\end{abstract}

Kata Kunci: Ekspor Sawit, Konflik Satwa-Manusia, Kesejahteraan Hewan

\title{
A. PENDAHULUAN
}

Parlemen Uni Eropa telah mengeluarkan kebijakan untuk menghentikan penggunaan Crude Palm Oil (CPO) sebagai bahan bakar nabati pada 13 Maret 2019 (Pablo \& Arvirianty, 2019). Ada lima alasan Parlemen Uni Eropa mengeluarkan kebijakan larangan impor CPO dan produk turunannya, yaitu industri sawit menciptakan deforestasi, degradasi habitat satwa, korupsi, mempekerjakan anak, dan pelanggaran Hak Asasi Manusia (HAM). Parlemen Uni Eropa menganggap industri sawit Indonesia sebagai salah satu pemicu masalah-masalah tersebut. Alasan tersebut disetujui oleh 640 anggota Parlemen Uni Eropa, sedangkan 18 lainnya menolak, dan 28 memilih abstain (Sidik, 2018: 2-5).

Indonesia merespons keputusan Parlemen Eropa untuk menghentikan penggunaan minyak sawit untuk bahan bakar nabati sebagai kampanye hitam. Indonesia melalui Kementerian Koordinator Kemaritiman berupaya melawan narasi kampanye hitam Uni Eropa terhadap sawit dengan berbagai cara. Pemerintah Joko Widodo menunjuk Luhut Binsar Pandjaitan sebagai ketua tim negosiator untuk melawan "diskriminasi sawit" yang dilakukan oleh Uni Eropa. Luhut Binsar Pandjaitan selaku Menko Kemaritiman sekaligus tim negosiator mengklaim bahwa bisnis sawit telah berhasil menurunkan angka kemiskinan dan menciptakan lapangan kerja bagi 20 juta pekerja di Indonesia (Kunjana, 2019; Thomas, 2019; Yasmin, 2019).

Pemerintah juga berupaya mengkaji kemungkinan dilakukannya pemboikotan terhadap produk Eropa sebagai respons terhadap "diskriminasi sawit" (Adi, 2019; S.Utami, 2019). Luhut Binsar Pandjaitan selaku tim negosiator Indonesia pada pertemuan World Economic Forum (WEF) di Davos, Swiss menyatakan bahwa Indonesia sudah mampu mengelola perkebunan sawit sendiri secara berkelanjutan (Nirmala, 2019). Tim negosiator juga berupaya bertemu dengan Komisioner Perdagangan Uni Eropa dan Direktur Lembaga Kepausan untuk Keadilan dan Perdamaian Vatikan untuk membatalkan keputusan Uni Eropa dalam mengurangi penggunaan CPO sebagai bahan bakar nabati (Mohammad, 2018). 
Ketakutan pemerintah Indonesia untuk menyebut keputusan Uni Eropa (UE) sebagai "kampanye hitam", sebenarnya terkesan berlebihan disebabkan oleh ekspor sawit yang diproyeksikan akan terus meningkat. Di tengah gencarnya kampanye negatif, ekspor sawit Indonesia ke UE hingga tahun 2018 tetap menunjukkan grafik peningkatan. Berdasarkan data Badan Pusat Statistik (BPS) misalnya, mencatat kenaikan sebesar 851\% ekspor biodiesel Indonesia ke UE atau dari 164 ribu kiloliter pada 2016 menjadi 1,56 juta kiloliter pada 2018 (Edi, 2019). Meskipun permintaan minyak kelapa sawit untuk bahan bakar transportasi bisa jadi menurun akibat revisi Arahan Energi Terbarukan UE, permintaan minyak kelapa sawit untuk kepentingan industri, makanan, kosmetik, dan lainnya diproyeksikan akan tetap meningkat, bahkan tanpa adanya tambahan permintaan untuk biodiesel, permintaan global akan minyak kelapa sawit diperkirakan akan terus meningkat (Permatasari et al., 2018).

Selain usaha melawan kampanye negatif, pemerintah Indonesia terus berusaha melakukan berbagai cara untuk mempraktikkan tata kelola sawit yang berkelanjutan demi menjaga citra baik bisnis CPO. Tata kelola berkelanjutan ditujukan untuk mencegah terjadinya deforestasi, ancaman terhadap keanekaragaman hayati, dan mengurangi terjadinya potensi konflik akibat ekspansi perkebunan sawit. Pemerintah telah berupaya melakukan moratorium ekspansi sawit melalui Instruksi Presiden (Inpres) nomor 8 tahun 2018 tentang Penundaan dan Evaluasi Perizinan Perkebunan Kelapa Sawit serta Peningkatan Produktivitas Perkebunan Kelapa Sawit (Sawit Watch, 2019: 25-27).

Hasil penelitian dari jaringan organisasi masyarakat sipil menunjukkan bahwa pelaksanaan moratorium tersebut belum maksimal, sehingga deforestasi akibat ekspansi perkebunan tetap berjalan. Perkembangan kerja-kerja implementasi Inpres Nomor 8 Tahun 2018 dalam waktu 6 bulan (semester awal) sejak diterbitkan, beberapa kementerian/lembaga yang mendapatkan mandat masih belum optimal dalam melakukan pekerjaanya yang masih terbatas pada persiapan dan koordinasi antarinstitusi di pusat dan daerah. Dari 25 provinsi dan 247 kabupaten/ kota yang mempunyai perkebunan sawit, mayoritas belum memberikan respons terhadap Inpres Nomor 8 tahun 2018. Hasil pantauan aliansi organisasi masyarakat sipil menunjukkan bahwa 19 provinsi dan 239 kabupaten/kota belum memberikan responsnya (Sawit Watch, 2019: 25-27).

Pemerintah juga tetap melegitimasi konversi hutan menjadi perkebunan sawit dengan argumentasi pengentasan kemiskinan. Pertimbangan yang berbeda memang berlaku untuk pembangunan ekonomi dan pengentasan kemiskinan dibanding pertimbangan keanekaragaman hayati. Pilihan yang dibuat dalam kebijakan akan tergantung pada nilai di mana para pihak terlibat perannya pada tipe-tipe hutan tertentu dan penggunaan lahan, dan pada tujuan dan minatnya. Sasaran seperti pengentasan kemiskinan, pembangunan ekonomi, dan pengawetan keanekaragaman hayati akan selalu bertentangan satu sama lainnya, tetapi dengan transparansi dan kerangka kebijakan nasional yang demokratis akan mendorong tata kelola sawit yang berkelanjutan (Dijk \& Savenije, 2011: 18-20).

Pemerintah berupaya melakukan pengentasan kemiskinan melalui bisnis CPO sekaligus mencegah deforestasi melalui dana sawit yang dikelola oleh Badan Pengelola Dana Perkebunan Kelapa Sawit (BPDPKS) sejak tahun 2015. Akan tetapi, riset yang dilakukan oleh Nurfatriani et al. (2018) menunjukkan bahwa besarnya penerimaan negara dari sektor perkebunan dan industri minyak sawit ternyata belum sepenuhnya diimbangi dengan adanya kebijakan ekonomi dan fiskal yang berperan dalam memberi insentif bagi para pelaku usaha dan para pihak untuk mewujudkan perkebunan kelapa sawit berkelanjutan.

Dana sawit diberikan untuk kegiatan peremajaan, penelitian, pengembangan sumber daya manusia (SDM), promosi, dan sarana prasarana, sehingga tidak perlu melakukan 
pembukaan kawasan hutan. Meskipun, realisasinya sebanyak $89 \%$ dari dana sawit justru digunakan sebagai subsidi pengembangan biodiesel sebagai upaya menstabilkan harga CPO yang jatuh akibat over supply, sehingga dapat diserap oleh pasar biodiesel dan sisanya baru dipergunakan untuk pencegahan deforestasi (Nurfatriani, Ramawati, Sari, \& Komarudin, 2018b: 1). Pendapatan dari sektor pajak yang dikenakan kepada produk kelapa sawit dan turunannya serta pajak perkebunan (pajak pertambahan nilai/PPN dan pajak penghasilan/PPh) dikelola dan disetor ke pemerintah pusat dan kembali ke daerah dengan mekanisme dana perimbangan (Nurfatriani, Ramawati, Sari, \& Komarudin, 2018: 30-37).

Namun demikian, peningkatan produksi CPO dan nilai ekspor minyak kelapa sawit serta luasan kebun sawit tidak diiringi oleh persentase penerimaan pajak sektor sawit yang justru menurun. Belum adanya mekanisme dana bagi hasil yang berasal dari sektor perkebunan kelapa sawit, seperti halnya sektor kehutanan dan pertambangan, yang langsung disalurkan ke daerah-daerah penghasil menjadi salah satu isu penting bagi para pihak di daerah. Hal tersebut menjadi disinsentif dalam upaya mendorong peran pemerintah daerah di dalam mengawasi dan membangun perkebunan kelapa sawit yang berkelanjutan (Nurfatriani, Ramawati, Sari, \& Komarudin, 2018: 32-35).

Masalah yang muncul dalam pengelolaan dana sawit yang dihimpun dan dikelola oleh BPDPKS sejak tahun 2015 yang menjadi amanat Undang-Undang No. 39 tahun 2014 tentang Perkebunan dalam rangka mendukung sebagian pembiayaan penyelenggaraan sektor perkebunan kelapa sawit berkelanjutan mendorong kerusakan lingkungan hidup terus terjadi. Dana sawit tersebut telah disalurkan untuk berbagai kepentingan, seperti program mandatory pemanfaatan biodiesel, peremajaan, penelitian, dan pengembangan. Timpangnya alokasi dana sawit yang diberikan untuk penyediaan dan pemanfaatan biodiesel dengan yang dialokasikan untuk program peremajaan perkebunan rakyat telah menimbulkan polemik di antara para pihak. Masalah pengelolaan dana sawit telah membuat pihak-pihak yang tidak memiliki modal yang cukup untuk melaksanakan perkebunan sawit berkelanjutan pada akhirnya terpaksa merambah hutan demi keberlangsungan bisnisnya (Nurfatriani, Ramawati, Sari, \& Komarudin, 2018: 52-55)

Usaha tetap menjaga keanekaragaman hayati di tengah konversi hutan untuk perkebunan sawit juga diakomodasi melalui skema Roundtable Sustainable Palm Oil (RSPO). Pelaksanaan RSPO untuk memastikan bahwa bisnis sawit tidak merusak lingkungan dan habitat satwa liar bukan tanpa hambatan. Studi yang dilakukan oleh Erman (2017) menemukan bahwa Indonesia dan Malaysia sebagai negara eksportir sawit terbesar justru melakukan berbagai siasat untuk mengelabui RSPO yang mendorong perlindungan lingkungan terabaikan.

Aktor-aktor negara produsen utama sawit yang terbukti tidak terkooptasi dengan RSPO membuat sertifikasi tandingan, yakni ISPO di Indonesia dan MSPO di Malaysia. Kedua sertifikat tandingan ini bersifat mandatory, memiliki sanksi hukum, dan, seperti RSPO, mengutamakan prinsip keberlanjutan lingkungan dan keadilan sosial. Walaupun demikian, persoalan ketidakberlanjutan lingkungan dan keadilan sosial diklaim semata merupakan bahan kampanye gerakan masyarakat sipil di Eropa (Erman, 2017: 7-11).

Penelitian yang dilakukan oleh Chris (2018) menemukan bahwa sertifikasi memiliki nilai sebagai cara untuk meningkatkan kinerja lingkungan hidup dan sosial dalam pertanian, tetapi mendukung sertifikasi tidak bisa berjalan bersama (mutually exclusive) dengan pemahaman bahwa cara terbaik untuk mengurangi dampak dari industri minyak sawit pada saat sekarang adalah dengan menurunkan permintaan untuk minyak sawit. Khususnya, hingga sertifikasi mencapai $100 \%$ produksi, sertifikasi tidak mampu atau tidak dirancang untuk menangani efek-efek perubahan penggunaan lahan tidak langsung. Bahkan jika 
standar RSPO diperkuat demi melarang deforestasi dan konversi gambut, dan jikapun setengah dari perkebunan kelapa sawit di dunia telah mendapatkan sertifikasi RSPO, hal ini pun masih meninggalkan cakupan yang sangat besar untuk deforestasi dan penghancuran gambut di setengah bagian yang lain (Chris, 2018: 58-60). Akibatnya, satwa-satwa liar kehilangan habitatnya dan terpaksa masuk ke permukiman, sehingga memicu terjadinya konflik satwa-manusia.

Riset lain yang dilakukan oleh Greenpeace (2013) semakin menunjukan bahwa skema RSPO yang diterapkan dalam bisnis sawit tidak mampu mengatasi problem hilangnya habitat hewan dan konflik satwa-manusia. Standar RSPO gagal untuk melarang deforestasi dan konversi lahan gambut. Sebagaimana diungkapkan investigasi Greenpeace, anggotaanggota penting RSPO terlibat dengan perusakan habitat harimau, termasuk konversi lahan gambut, dan terimplikasi kebakaran besar pada bulan Juni 2013. Sementara itu, perkebunan sawit mengancam habitat harimau di Sumatra, situasi serupa juga terjadi pada orang utan di Sumatra dan Kalimantan. Semua orang utan terancam punah dan orang utan Sumatra terancam punah secara kritis (Greenpeace, 2013: 7-11).

Sayangnya, studi-studi di atas tidak menunjukan secara langsung bagaimana usaha pemerintah untuk menjaga citra bisnis sawit dalam pasar ekspor dan berimbas pada ancaman penghidupan satwa terdampak serta eskalasi konflik yang muncul antara hewan liar dan manusia. Usaha pemerintah dalam menjaga citra positif bisnis CPO untuk meningkatkan ekspor sawit seolah telah kurang memandang penting penyelesaian terhadap eskalasi konflik satwa-manusia yang muncul akibat ekspansi perkebunan. Kondisi habitat hewan liar yang rusak tidak diekspose ke publik disebabkan oleh ketakutan terhadap hal-hal yang mengancam citra bisnis sawit, sehingga dapat mengganggu upaya peningkatan ekspor. Kajian ini ingin mendalami bagaimana peran negara dan berbagai aktor berkepentingan dalam menjaga peningkatan ekspor sawit telah menyebabkan tetap bertahannya eskalasi konflik satwa-manusia. Pendalaman terhadap konflik satwa-manusia yang terimbas ambisi peningkatan ekspor sawit ini penting dilakukan untuk mengevaluasi bagaimana tata kelola buruk telah menyebabkan hewan liar terusir dari habitatnya dan semakin terancam kehidupannya. Ambisi peningkatan ekspor sawit ini juga perlu diselidiki apakah telah mengorbankan peri kehidupan hewan liar yang terpaksa mencari makan di permukiman dan berujung pada jatuhnya korban bagi satwa.

\section{B. METODE PENELITIAN}

Penelitian ini adalah riset kualitatif deskriptif yang berusaha menjelaskan dampak konflik satwa-manusia yang muncul akibat ambisi pemerintah Indonesia dalam meningkatkan ekspor sawit. Pengkajian dikerangkai dengan konsep animal welfare untuk mengambarkan bagaimana pilihan pemerintah untuk semata meningkatkan ambisi ekspor telah meminggirkan peri kehidupan satwa liar yang terdampak ekspansi sawit. Penelitian ini dilakukan dengan desk study untuk melakukan penelusuran terhadap berbagai laporan pemerintahan, artikel jurnal, berita, dan berbagai laporan lembaga swadaya masyarakat yang fokus pada pengawalan isu sawit dari hulu sampai hilir. Analisis data dilakukan selama proses pengkajian melalui beberapa tahapan, yakni reduksi data, penyajian data, verifikasi, dan penarikan kesimpulan.

\section{KERANGKA TEORI}

Sudut pandang animal welfare telah berkembang di tengah kepedulian para cendekiawan untuk mulai memikirkan mengenai nasib kehidupan hewan akibat interaksi dan pemenuhan kebutuhan manusia. Di tengah sudut pandang konvensional yang berusaha 
mengedepankan pemenuhan kebutuhan manusia dengan berbagai sumber daya mulai muncul kepedulian dari para ilmuwan untuk membangun etika dan moral lingkungan tentang pentingnya menjaga hubungan lintas spesies termasuk dengan hewan (Jordan, 2005: 518521).

Sudut pandang animal welfare telah mendorong perlunya perlakuan yang semestinya pada hewan untuk dapat diperlakukan dengan baik dan menjaga kelangsungan hidupnya. Hewan dianggap memiliki kebutuhan dasar yakni hak hidup yang harus dijamin pula oleh institusi negara, sehingga baik hak manusia dan binatang sama-sama penting. Hewan juga dipandang memiliki sisi psikologis yang dapat terancam akibat gangguan dari spesies lain seperti manusia. Studi-studi yang dikompilasi oleh Jordan (2005) telah melihat bagaimana minimnya pemenuhan hak hidup hewan yang dapat meminggirkan peri kehidupannya. Aspek kesejahteraan hewan menyangkut hak hidup di lingkungannya, perhatian terhadap naluri alamiahnya, perlindungan dari ancaman berkurangnya populasi, dan lain-lain. Kesejahteraan hewan sering terganggu akibat binatang coba "ditaklukkan" oleh manusia dengan perlakuan yang buruk dengan ditempatkan di kebun binatang, penangkaran, sirkus, dan lain-lain. Kecenderungan dominasi pandangan antroposentris yang memandang hewan semata alat pemenuhan kebutuhan bagi manusia telah mendorong terpinggirkannya kesejahteraan hewan (Jordan, 2005: 518-521).

Aktivitas manusia telah menggerus peri kehidupan hewan di habitatnya. Berbagai aktivitas yang diawali deforestasi, penangkapan binatang, pembukaan lahan untuk industri/permukiman, dan lain-lain tanpa melihat jaminan terhadap kehidupan satwa telah memicu ketegangan lintas spesies. Kesejahteraan hewan semakin dikoyak dengan memandang hewan sebagai objek eksploitasi ekonomi untuk memenuhi kebutuhan manusia (Brakes, 2019: 4-6). Interaksi antara manusia dan hewan terjadi sangat dipengaruhi oleh perubahan lanskap ekosistem.

Manusia yang dengan cepat merubah lanskap lahan tanpa melihat jaminan peri kehidupan hewan telah menyebabkan adanya peningkatan intensitas interaksi antara penduduk dengan binatang. Tak jarang interaksi akibat perubahan lanskap lahan tersebut berujung pada kalahnya hewan, sehingga peri kehidupannya terpinggirkan. Hal tersebut telah memicu konflik di antara kedua spesies yang terus mendorong peminggiran kesejahteraan hewan (Brakes, 2019: 4-6). Konflik satwa-manusia telah mendorong hewan kehilangan habitatnya dan menghadapi ancaman penurunan populasi. Ketika manusia menganggap hewan akan mengganggu pemenuhan kehidupan, maka mereka tak segan menyerang, melukai bahkan membunuh hewan. Manusia juga menjadi tidak akan peduli dengan keseimbangan alam dengan adanya keberadaan hewan disebabkan lebih akan mengutamakan pemenuhan kebutuhannya (Madden, 2008: 190-192).

Konflik satwa-manusia secara sederhana dapat dimaknai sebagai segala interaksi baik itu yang disebabkan manusia, alam, maupun keduanya yang berdampak negatif atau adanya pihak yang dirugikan (Lubis, Afifuddin, \& Patana, 2014: 1-2). Berbagai studi mengenai konflik satwa-manusia di Indonesia kebanyakan lebih mengkaji terkait upaya mitigasi yang dilakukan manusia untuk menyelamatkan kepentingan produksinya. Satwa liar yang mengganggu aktivitas produksi manusia dianggap sebagai hama, sehingga harus diusir atau dipindahkan ke tempat lain. Berbagai usaha mitigasi konflik satwa-manusia pada dasarnya dilakukan untuk mencegah lahan produksi milik manusia agar tidak dirusak oleh hewan liar. Riset yang dilakukan oleh Fitra Lubis, Afiduddin, dan Patana di perkebunan sekitar Taman Nasional Gunung Leuser menemukan bahwa usaha penjagaan warga dengan meriam karbit dan penangkapan serta pemindahan orang utan dari kebun sebenarnya kurang efektif dan efisien dalam upaya penyelamatan satwa (Lubis et al., 2014: 3-5). 
Kebanyakan warga yang terdampak dengan konflik satwa-manusia berpandangan bahwa masuknya hewan liar ke lahan pertanian dan permukiman sebagai gangguan. Hewan liar selalu mendapatkan stigma negatif sebagai perusak lahan pertanian akibat habitatnya yang telah rusak. Riset yang dilakukan oleh Abdullah dan Hilmayanti (2017) dengan mengambil kasus di Aceh Besar menemukan bahwa warga terdampak konflik satwamanusia lebih menyerahkan upaya penyelamatan satwa semata kepada pemerintah (Abdullah \& Hilmayanti, 2017: 17-18). Warga selalu berusaha mempertahankan permukiman dan lahan pertaniannya, meskipun mereka tetap bergantung pada hutan dalam memenuhi kebutuhan. Masih banyak warga yang kurang melihat pentingnya keberadaan satwa liar sebagai bagian penting keseimbangan hutan tempat di mana mereka juga menggantungkan hidup (Abdullah \& Hilmayanti, 2017: 17-18; Fredriksson, 2005: 134-136; Rianti \& R.Garsetiasih, 2017: 81-83).

Warga yang minim mendapatkan sosialisasi mengenai penyelamatan satwa terkadang melakukan upaya ekstrem untuk menyelesaikan konflik dengan hewan liar (Abdullah \& Hilmayanti, 2017: 81-83). Warga tidak segan untuk mengusir hewan liar dengan tembakan, menjerat, menyetrum hingga meracun. Warga justru menginginkan satwa dipindahkan, karena hewan liar dianggap mengganggu ladang pertanian dan perkebunan masyarakat setiap menjelang musim panen dan musim kering. Padahal, satwa yang terjebak dalam konflik satwa-manusia berstatus sebagai hewan yang dilindungi ataupun terancam punah (Abdullah \& Hilmayanti, 2017: 17-18; Qomariah, Rahmi, Said, \& Wijaya, 2019: 79-90; Rianti \& R.Garsetiasih, 2017: 81-83). Celakanya, nasib malang satwa diperparah dengan merebaknya perburuan yang dianggap juga sebagai solusi untuk mencegah masuknya binatang liar ke lahan pertanian dan permukiman (Prayudhi, 2015: 9-12).

Kepasrahan warga untuk menyerahkan penyelesaian jangka panjang mengenai konflik dengan satwa yang mereka hadapi kepada negara sebenarnya cukup beralasan. Tumpang tindih konsesi dan perizinan yang dikeluarkan oleh pemerintahlah yang memicu rusaknya habitat satwa dan mendorong mereka mencari sumber makanan di tempat lain (Andyono, Marsono, Sadono, \& Imron, 2018: 19-22). Sering kali, pemerintah sengaja mengubah atau membiarkan adanya peruntukan kawasan konservasi sebagai lokasi produksi perkebunan sawit, pertambangan, hutan produksi, dan lain-lain (Qomariah et al., 2019: 81-83).

Akibatnya, habitat satwa yang telah dikonversi untuk aktivitas produksi manusia menyebabkan intensitas interaksi binatang liar dengan manusia semakin meningkat. Penelitian yang dilakukan oleh Andyono, Marsono, Sadono, dan Imron (2018) di kawasan konservasi Way Kambas menemukan bahwa kepentingan pemangku kepentingan yang berbeda-beda dalam pemanfaatan lahan telah menghambat upaya penyelesaian konflik satwa-manusia. Riset lain yang dilakukan oleh Gunawan, Iskandar, Sihombing, dan Wienanto (2017) menjelaskan bahwa usaha penyelesaian konflik satwa-manusia yang diambil negara juga tak lebih dari upaya melindungi kepentingan ekonomi manusia yang telah mengonversi hutan (Gunawan, Iskandar, Sihombing, \& Wienanto, 2017: 654-656). Salah satu ambisi pemerintah dalam memfasilitasi ekspansi perkebunan sawit juga semakin memperparah hilangnya habitat satwa.

Ekspansi sawit lewat berbagai skema perizinan telah menyebabkan kepentingan warga lokal terjebak dalam pusaran konflik dengan satwa. Riset yang dilakukan oleh Suba, dkk, (2017) misalnya telah membongkar bagaimana kehadiran perluasan perkebunan sawit di Kalimantan Utara meningkatkan eskalasi konflik antara gajah dan manusia. Warga lokal dengan bantuan organisasi masyarakat sipil berusaha menghalau binatang liar yang masuk ke permukiman dan lahan pertanian di tengah ketidakhadiran negara (Suba et al., 2017: 8$\underline{10)}$. 
Usaha negara untuk memfasilitasi ekspansi perkebunan sawit telah menunjukan jaminan hidup satwa dinomorduakan. Kajian yang dilakukan oleh Kamim (2018) menemukan bagaimana proses komodifikasi, privatisasi tanah, dan pengusiran paksa populasi dan konversi berbagai bentuk hak milik (umum, kolektif, negara, dll.) menjadi hak milik pribadi eksklusif lewat ekspansi sawit menyebabkan privatisasi rimba. Hewan yang kehilangan ruang hidupnya terpaksa harus masuk ke lingkungan yang sudah diprivatisasi dan harus bersinggungan dengan korporasi. Hewan tidak memiliki kemampuan untuk menghadapi proses perampasan ini dan pada akhirnya mereka menjadi korban (Kamim, $\underline{2018)}$.

Sayangnya, kajian di atas belum mampu menjelaskan penyebab ekspansi sawit yang disebabkan oleh ambisi negara untuk menggenjot ekspor CPO. Ambisi tersebut telah berujung pada berbagai upaya negara untuk memastikan bahwa bisnis sawit mendapat citra positif di pasar ekspor, sedangkan eskalasi konflik satwa-manusia akibat ekspansi perkebunan kurang diperhatikan. Maka, kajian untuk mendalami implikasi ambisi meningkatkan ekspor sawit terhadap penyelesaian konflik satwa-manusia perlu dilakukan untuk memastikan bahwa pemenuhan hak hidup binatang liar benar-benar terpenuhi, demi menjaga keseimbangan alam.

\section{HASIL DAN PEMBAHASAN}

\section{Ambisi Peningkatan Ekspor Kelapa Sawit dan Kerusakan Keanekaragaman Hayati}

Pemerintah Indonesia dan industri sawit menganggap bahwa upaya Uni Eropa untuk mengurangi porsi biofuel dari sawit sebagai praktik "diskriminasi" dan "kampanye hitam", tetapi stigma tersebut tidak terbukti sama sekali. Jaringan organisasi masyarakat sipil sebenarnya telah mengeluarkan lembar fakta yang menunjukkan klarifikasi mengenai kesalahpahaman terhadap kebijakan Uni Eropa untuk mengurangi porsi sawit sebagai salah satu sumber energi terbarukan.

Lembar fakta yang dikeluarkan oleh jaringan organisasi masyarakat sipil di Indonesia menjelaskan bahwa sumbangsih bahan bakar nabati generasi pertama (semua minyak nabati berbasis pangan, seperti sawit) tidak akan ditingkatkan, tetapi porsi penggunaannya akan tetap pada batas atas sebesar $7 \%$ dari konsumsi akhir energi kotor di sektor transportasi (Permatasari et al., 2018). Khusus BBN (Bahan Bakar Nabati) dari minyak sawit untuk transportasi, listrik, dan pemanas, Parlemen Eropa mengusulkan agar tidak lagi diikutsertakan dalam perhitungan konsumsi akhir energi kotor dari energi terbarukan pada tahun 2021. Akibatnya, memang menyebabkan minyak sawit tidak akan lagi mendapatkan subsidi energi terbarukan dalam penggunaannya (Permatasari et al., $\underline{2018}$.

Komisi Uni Eropa dan Dewan Uni Eropa sendiri sebenarnya berbeda pandangan mengenai usulan Parlemen Eropa disebabkan mereka memiliki posisi dan pandangan yang berbeda. Komisi Uni Eropa mengusulkan bahan bakar nabati dari minyak sawit dalam perhitungan energi terbarukan, seharusnya tidak dinihilkan. Komisi Uni Eropa menginginkan porsi penggunaan minyak sawit dalam perhitungan energi terbarukan tetap berada di batas atas $7 \%$ hingga tahun 2020 dan dikurangi secara bertahap sampai mencapai 3,8\% pada tahun 2030. Sementara itu, posisi Dewan Uni Eropa tetap menginginkan porsi penggunaan minyak sawit tetap berada pada batas atas $7 \%$ (Permatasari et al., 2018).

Uni Eropa sendiri sebenarnya telah menetapkan kriteria keberlanjutan yang ketat dalam pemanfaatan semua jenis bahan bakar nabati generasi perrtama, agar dapat 
dimasukkan dalam perhitungan energi terbarukan. Pertama, harus ada komitmen untuk menurunkan gas rumah kaca sebesar 35\% dibandingkan dengan bahan bakar fosil (Permatasari et al., 2018). Target tersebut meningkat menjadi 50\% pada tahun 2017 dan meningkat menjadi $60 \%$ pada tahun 2018 khusus untuk pabrik baru. Kedua, bahan bakar nabati tidak boleh berasal dari lahan yang memiliki kandungan karbon tinggi seperti lahan basah (termasuk gambut) dan hutan. Ketiga, bahan bakunya tidak boleh berasal dari lahan yang memiliki keanekaragaman hayati tinggi, seperti hutan primer dan grassland (Permatasari et al., 2018).

Lembar fakta jejaring organisasi masyarakat sipil juga menjelaskan bahwa arahan UE tidak akan melarang impor maupun penggunaan bahan bakar nabati dari sawit di Uni Eropa. Minyak kelapa sawit kenyataannya akan tetap digunakan sebagai bahan bakar, pembangkit listrik, dan pemanas, tetapi hanya tidak akan dihitung sebagai penggunaan energi terbarukan. Dampaknya minyak sawit tidak akan mendapatkan insentif energi terbarukan seperti keringanan pajak, bantuan penelitian, investasi, sertifikat hijau yang diberikan untuk mendorong penggunaan energi yang dapat mengurangi gas rumah kaca (Permatasari et al., 2018).

Sebelumnya, Parlemen Eropa mengeluarkan resolusi pada bulan April tahun 2017 yang isinya mendorong Komisi Eropa untuk mengambil langkah untuk tidak menggunakan bahan bakar nabati penimbul deforestasi pada tahun 2020 tidak terbatas pada minyak kelapa sawit. Komisi Eropa sendiri belum mengambil langkah apapun terkait resolusi tersebut. Dengan demikian, berbagai pemberitaan di media massa yang menyatakan bahwa Uni Eropa akan melarang penggunaan bahan bakar nabati dari minyak kelapa sawit telah memunculkan kesalahpahaman (Permatasari et al., 2018).

Lembar fakta jejaring organisasi masyarakat sipil justru mampu menunjukan bahwa kebijakan biofuel Uni Eropa telah mendorong peningkatan konsumsi dan permintaan kelapa sawit secara global. Khususnya setelah Arahan Energi Terbarukan tahun 2009 diberlakukan, impor minyak kelapa sawit UE tumbuh sebesar 21\% pada periode 2010-2017. Hal ini menunjukkan kecenderungan bahwa setelah ada kebijakan bahan bakar nabati Uni Eropa, penggunaan minyak kelapa sawit untuk energi justru menggeser penggunaan minyak kelapa sawit yang digunakan dalam makanan dan industri (Permatasari et al., 2018).

Lembar fakta jejaring organisasi masyarakat sipil justru menunjukkan bahwa permintaan kelapa sawit untuk bahan bakar transportasi bisa jadi menurun akibat revisi Arahan Energi Terbarukan Uni Eropa, tetapi permintaan minyak kelapa sawit untuk kepentingan industri, makanan, kosmetik, dan lainnya diproyeksikan akan tetap meningkat. Tanpa adanya tambahan permintaan biodiesel pun, permintaan global terhadap konsumsi minyak kelapa sawit diperkirakan akan terus meningkat. Efek substitusi juga muncul akibat adanya kebijakan Uni Eropa. Kenaikan permintaan dan harga rapeseed oil di Uni Eropa akibat permintaan biodiesel ternyata berdampak pada peningkatan penawaran minyak kelapa sawit ke UE untuk menggantikan penggunaan rapeseed oil di sektor pangan. Kebijakan biodiesel di Indonesia yakni, penggunaan B20 pada 2020 dan B30 pada 2030) diperkirakan akan membuat adanya peningkatan permintaan secara langsung minyak kelapa sawit dalam jumlah besar. Akibatnya, ada atau tanpa kebijakan Uni Eropa, permintaan domestik terhadap minyak sawit tetap meningkat (Permatasari et al., 2018).

Pihak Uni Eropa melalui duta besarnya juga telah memberikan klarifikasi terhadap klaim sepihak terhadap dugaan "kampanye hitam" sawit dari Indonesia. Duta Besar Uni Eropa di Jakarta menjelaskan bahwa impor sawit Indonesia cenderung stabil. Uni Eropa 
mencatat bahwa impor CPO dalam lima tahun terakhir relatif stabil dengan rata-rata 3,6 juta ton atau 2,3 miliar euro per tahun. Selain itu, pangsa pasar CPO Indonesia di Uni Eropa tetap merupakan yang terbesar, yakni sekitar 49 persen. Uni Eropa tidak menerapkan kebijakan larangan impor minyak sawit, melainkan kebijakan energi berkelanjutan. Artinya, produk-produk biofuel yang masuk ke pasar Uni Eropa harus memenuhi standar dari kebijakan tersebut (Widyastuti, 2019).

Akan tetapi, pemerintah Indonesia dan industri sawit tetap menganggap langkah Uni Eropa sebagai upaya proteksionisme yang diambil. Pemerintah Indonesia berusaha memperjuangkan eksistensi minyak sawit disebabkan menjadi prioritas komoditi ekspor terbesar. Pemerintah Indonesia justru mengklaim bahwa pembukaan lahan yang digunakan untuk produksi minyak sawit menjadi potensi bagi terbukanya lowongan pekerjaan yang akan menyelesaikan masalah pengangguran (Sally, 2016: 7-9). Pemerintah Indonesia berusaha menyanggah langkah Uni Eropa dengan melakukan berbagai penelitian untuk menjaga legitimasi ekspansi sawit yang digunakan untuk memenuhi ambisi peningkatan ekspor. Pemerintah Indonesia menganggap bahwa langkah Uni Eropa hanya menjadi upaya proteksionisme. Langkah Uni Eropa dianggap sebagai upaya untuk melindungi penggunaan komoditas lain dari internal UE (Sally, 2016: 7-9).

Pemerintah Indonesia juga memperjuangkan minyak kelapa sawit dengan anggapan bahwa bahan bakar nabati dari komoditas lain lebih memberikan efek deforestasi yang besar. Kajian yang dilakukan Bonita (2018) menemukan bahwa dari keseluruhan lahan peruntukan bahan bakar nabati di seluruh dunia ternyata minyak kelapa sawit hanya membutuhkan $10 \%$ dari total keseluruhan wilayah produksi seluas 191 juta ha (Bonita, 2018: 5-9). Hal tersebut menjadi lebih sedikit dibandingkan dengan komoditas lain seperti rapeseed oil seluas 19\%, soybean oil $58 \%$, dan sunflower oil $13 \%$ dari keseluruhan lahan yang digunakan untuk produksi bahan bakar nabati (Bonita, 2018: 5-9).

Pemerintah Indonesia berusaha memfasilitasi ekspansi sawit untuk mengejar target ekspor yang terus meningkat dengan upaya konservasi lingkungan. Masalahnya nilai ekonomis sawit dan ketersediaan lahan untuk perkebunan dan pertanian telah mendorong para wirausahawan turun ke daerah dan pedesaan yang terisolasi untuk membuka kebun-kebun sawit (Apindo, 2017: 3-5). Meskipun mengklaim bahwa tetap akan menjaga lingkungan, sebenarnya pemerintah Indonesia lebih fokus untuk membuat kebijakan publik yang berpihak pada pertumbuhan ekonomi lewat ekspansi perkebunan sawit.

Ekspansi perkebunan sawit menjadi bentuk riil dari kebijakan publik yang digunakan untuk memfasilitasi akumulasi modal dibandingkan dengan menjaga keseimbangan lingkungan yang bisa menyebabkan hilangnya dan/atau berkurangnya secara signifikan habitat fauna. Kebijakan publik yang diklaim menjaga keseimbangan salah satunya melalui manajemen pengelolaan lahan gambut "berkelanjutan," sebenarnya tidak bisa dilepaskan dari langkah replanting sawit pada area seluas 2,4 juta hektar (Apindo, 2017, 1).

Mayoritas elite politik bahkan lebih berpihak kepada ekspansi sawit dibandingkan terjaganya habitat di kawasan hutan. Berdasarkan studi terhadap proses RUU Perkelapasawitan bahkan menjelaskan bahwa mayoritas anggota Badan Legislatif DPR RI cenderung mendukung rancangan undang-undang yang menguntungkan ekspansi perkebunan, meskipun pemerintah telah menyatakan penolakannya demi kepentingan nasional (Fetra, Apriliana, \& Putra, 2019: 9-10). Keterkaitan antara wakil rakyat dengan 
korporasi besar sawit dan menimbulkan konflik, faktanya tidak menjamin adanya keberpihakannya pada kepentingan masyarakat atas lingkungan hidup. Para elite politik mendukung pengalihfungsian hutan menjadi wilayah perkebunan dibandingkan menjadikannya konservasi alam juga disebabkan oleh keterkaitan pejabat teras partai baik secara kepemilikan ataupun relasi industri monokultur ini (Fetra et al., 2019: 9-10).

Pemerintah mengeluarkan regulasi dalam pengelolaan gambut seperti melalui PP No. 57/2016 jo PP No. 71/2014 tentang Perlindungan dan Pengelolaan Ekosistem Gambut dan peraturan pelaksanaannya yang terdiri dari 4 Peraturan Menteri yaitu Permen Lingkungan Hidup dan Kehutanan (LHK) No. 14/2017, No. 15/2017, No. 16/2017, serta Keputusan Menteri LHK No. SK.129 Tahun 2017 dan No. SK.130 Tahun 2017 (Apindo, 2017: 2-5). Akan tetapi, realitasnya regulasi yang ada tidak mampu membawa keseimbangan antara aspek sosial, lingkungan, dan ekonomi. Hal tersebut disebabkan semenjak awal kebijakan publik yang dibuat oleh pemerintah lebih memihak pada fasilitasi ekspansi sawit (Apindo, 2017: 2-5).

Kebijakan publik yang tidak memihak pada konservasi lingkungan dan lebih mendukung fasilitasi peningkatan ekspor sawit kenyataannya justru tetap menyebabkan ekspansi perkebunan terus terjadi (Purnomo, Okarda, Dermawan, Ilham, \& Bizarani, 2017: 34-36). Ekonomi minyak sawit dan konservasi lingkungan sering kali berkonflik dan bertolak belakang disebabkan semenjak awal pemerintah lebih mengadopsi rezim "pasar bebas" dibandingkan regime "konservasi." Berbagai langkah yang diambil melalui moratorium, produktivitas, lahan gambut, pertukaran lahan, dan reformasi agraria bahkan justru meningkatkan ekspansi perkebunan dan diperparah dengan pengalihan area produksi di lahan gambut (Purnomo, Okarda, Dermawan, Ilham, \& Bizarani, 2017: 34-36).

Kontestasi antara rezim pasar bebas dan regime konservasi menunjukkan adanya pertarungan antara kepentingan perlindungan lingkungan, pemenuhan hak-hak hewan, dan kepentingan pertumbuhan modal. Keputusan pemerintah untuk menjaga kepentingan pertumbuhan modal lewat ekspansi sawit telah dikaburkannya keperluan hak-hak hewan dan perlindungan lingkungan. Proses kompromi antara dua keperluan kenyataannya selalu bertolak belakang disebabkan oleh kerusakan habitat hewan justru bertambah parah (Hutchins \& Wemme, 1987: 122-125). Pertumbuhan populasi hewan liar yang terganggu untuk spesies tertentu, tapi meningkatkan jumlah spesies lain kenyataannya justru membawa kerugian bagi ekonomi sawit. Degradasi lingkungan justru menyebabkan hewan-hewan perusak tanaman sawit menyerbu perkebunan akibat habitatnya rusak. Pengalihfungsian hutan menjadi perkebunan sawit justru menyebabkan etika lingkungan dan penghambatan reproduksi berbagai spesies yang dilindungi, sehingga meningkatkan angka kematian satwa. Upaya penangkapan dan translokasi secara langsung terhadap binatang liar yang terdampak pengalihfungsian hutan semakin menunjukkan kontrol rezim pasar bebas terhadap pertumbuhan populasi hewan (Hutchins \& Wemme, 1987: 122-125).

Sertifikasi lingkungan baik melalui RSPO (Roundtable Sustainable Palm Oil) dan ISPO (Indonesia Sustainable Palm Oil) tidak efektif dalam menjaga komitmen pelaku industri sawit dalam menyeimbangkan ekonomi pasar dengan rezim konservasi. Hal tersebut disebabkan oleh sertifikasi lingkungan yang ada bersifat sukarela. Sertifikasi ISPO \& RSPO bukan instrumen untuk mengatur dan mengawasi (Indrapraja, 2018: 5153). Hal tersebut membuat ISPO menjadi duplikatif dengan instrumen command and control lain yang sudah ada. Sertifikat RSPO juga tidak memiliki daya paksa dan 
kekosongan peran pemerintah dalam pengawasan dan pemberian insentif atas perilaku pelaku industri sawit yang "prokonservasi" (Indrapraja, 2018: 51-53).

Sertifikasi sebenarnya dilakukan untuk meningkatkan kinerja lingkungan hidup dan sosial dalam pertanian, tetapi mendukungnya tidak bisa berjalan bersama dengan pemahaman bahwa cara terbaik untuk mengurangi dampak dari industri minyak sawit dengan menurunkan permintaannya. Khususnya, sertifikat mencapai $100 \%$ produksi tidak akan mampu menangani efek-efek perubahan penggunaan lahan tidak langsung. Bahkan, apabila standar RSPO diperkuat, cakupan untuk deforestasi dan penghancuran gambut akan tetap terjadi (Malins, 2017: 6-8).

Langkah lain dilakukan pemerintah Indonesia semenjak Mei tahun 2010 mengumumkan bahwa kebijakan perkebunan sawit di lahan kritis untuk mencegah penggundulan hutan yang berdampak pada hilangnya habitat satwa. Akan tetapi, kebijakan tersebut tak lain semata untuk memfasilitasi ekspansi perkebunan sawit untuk mengakuisisi 6 juta hektar lahan kritis (Amelia, 2017: 5-9). Keberhasilan produksi kelapa sawit di lahan kritis sangat bergantung pada kualitas lahan yang tersedia. Penggunaan lahan kritis kenyataannya tidak efektif dalam memfasilitasi produksi sawit, sehingga tetap menyebabkan deforestasi akibat ekspansi perkebunan.

Berkembangnya kebun sawit di lahan yang diklaim sebagai kawasan hutan menunjukan bahwa insentif membangun kebun sawit lebih tinggi dibandingkan dengan komoditas lainnya atau pengusaha masih melihatnya sebagai komoditas yang paling memberikan nilai ekonomi tertinggi. Kontestasi peruntukan lahan terjadi dalam upaya memfasilitasi ekspansi sawit dibandingkan memfasilitas konservasi lingkungan. Pemerintah sayangnya tidak melihat daya dukung lingkungan dan lebih memilih memfasilitasi ekspansi sawit.

Komisi Pemberantasan Korupsi melalui temuannya pada tahun 2016 bahkan menjelaskan bahwa verifikasi teknis terhadap ekspor sawit, CPO (Crude Palm Oil), dan produk turunannya tidak akurat. Meskipun data dari Apindo menunjukkan bahwa selama tahun 2016, nilai ekspor kelapa sawit mencapai USD 18,23 miliar,meningkat kembali setelah pada 2015 sedikit mengalami penurunan. Kenaikan nilai ekspor kelapa sawit disebabkan adanya kenaikan harga CPO global sekitar 41,4\%selama 2016. Berdasarkan negara tujuan, India merupakan tujuan ekspor minyak sawit terbesar Indonesia di tahun 2015 dengan nilai FOB mencapai USD 3,22 miliar (20,91\% dari total ekspor sawit Indonesia). Disusul Tiongkok (13,30\%) yang mencapai USD 2,05 miliar. Sementara itu, negara Uni Eropa pengimpor minyak sawit terbesar adalah Belanda dan Jerman dengan nilai USD 821,2 juta (5,34\% dari total ekspor sawit Indonesia). Data dari Apindo sendiri juga menunjukkan peningkatan ekspor sawit menyebabkan pengusahapengusaha melakukan ekspansi perkebunan di "daerah terisolasi" dan melakukan pembukaan hutan (Apindo, 2017: 2-3).

Perkebunan sawit tidak berkelanjutan seperti yang dikhawatirkan oleh Uni Eropa kenyataannya bukanlah sekadar tuduhan semata. Data dari Centre for Orangutan Protection (2009) menunjukkan bagaimana keterlibatan perusahaan dalam skema RSPO tidak mendorong mereka untuk mematuhi prinsip-prinsip perkebunan sawit berkelanjutan. Perusahaan-perusahaan sawit yang tergabung dalam skema RSPO di Kalimantan Tengah tetap melakukan tindakan pembabatan hutan bahkan melakukan pembantaian terhadap orang utan. Pasca dilaksanakannya forum RSPO pada tahun 2007 di Singapura, Centre for Orangutan Protection melakukan pengecekan terhadap hutanhutan yang tersisa tempat dipindahkannya orang utan dari sekitar perkebunan sawit (Centre for Orangutan Protection, 2009). Temuan Centre for Orangutan Protection 
menunjukkan orang utan yang dipindahkan tidak ada yang tersisa disebabkan hutan telah terdampak ekpansi sawit.

Celakanya dibandingkan menyelesaikan problem perkebunan sawit tidak berkelanjutan, pemerintah Indonesia justru terus menetapkan target ambisius dari ekspor $\mathrm{CPO}$. Indonesia telah mengumumkan rencananya untuk melipatgandakan produksi minyak kelapa mentahnya pada tahun 2025, suatu target yang akan membutuhkan 2 kali lipat peningkatan hasilnya dibandingkan dengan keberhasilan negara tetangganya, Malaysia atau justru memperluas daerah yang akan ditanami kelapa sawit. Indonesia sepertinya akan menggunakan kedua pilihan yang ada. Sesuai usulan investasi tahun 2005 yang dibuat oleh Perusahaan Perkebunan Negara PT Perkebunan Nusantara (PTPN), Indonesia akan mengembangkan sekitar 1,8 juta hektar di kawasan perbatasan Indonesia-Malaysia, di mana sebagian besar berstatus sebagai kawasan hutan (Butler, $\underline{2008)}$.

\section{Rezim Lisensi dan Tergerusnya Habitat Hewan}

Rezim perizinan (lisensi) dijadikan sebagai landasan utama praktik pengusahaan perkebunan sawit. Rezim perizinan telah menyebabkan tumpang-tindih penggunaan lahan baik untuk perkebunan sawit maupun peruntukan konservasi. Terdapat beberapa tipologi tumpang-tindih dalam memfasilitasi perkebunan sawit yang ada di Indonesia, yakni: Pertama, konflik antara masyarakat dengan perusahaan perkebunan; konflik masyarakat dengan negara; konflik perusahaan dengan negara; dan perusahaan dengan perusahaan yang memperparah kerusakan habitat satwa (Soedomo et al., 2018: 49-55).

Permasalahan tumpang-tindih lahan telah menyebabkan kondisi habitat satwa semakin rusak. Upaya moratorium lahan gambut dan hutan untuk peruntukan perkebunan sawit tidak pernah serius dalam menyelesaikan tumpang-tindih yang terjadi. Upaya pelepasan status kawasan hutan di Indonesia kenyataannya terus terjadi melalui revisi tata ruang maupun perubahan status lahan secara parsial akibat perkebunan kelapa sawit. Perubahan peruntukan kawasan hutan melalui mekanisme revisi tata ruang cenderung mengalami peningkatan selama masa moratorium. Tahun 2011 terjadi pelepasan kawasan hutan seluas 159.300 hektar, dan pada 2012 mengalami peningkatan lebih dari 10 kali lipat yakni seluas 1,8 juta hektar (Forest Watch Indonesia, 2016: 5-7).

Tahun 2013 kembali dilepaskan kawasan hutan seluas 2,4 juta hektar, dan puncaknya tahun 2014, dimana terjadi pelepasan kawasan hutan hingga 3,2 juta hektar. Selama masa moratorium, Pemerintah telah melepaskan kawasan hutan secara parsial untuk perkebunan seluas 1.677.217 hektar, dengan rincian 944.071 hektar pada masa moratorium 2011-2013, seluas 645.005 hektar pada masa moratorium 2013-2015, dan terus terjadi pelepasan kawasan hutan untuk perkebunan pada masa moratorium 2015-2017 meski angkanya lebih kecil yakni 88.140 hektar (Forest Watch Indonesia, 2016: 5-7).

Sawit telah menjadi pendorong deforestasi setelah sebelumnya pembukaan hutan lebih disebabkan oleh skema HPH (Hak Pengusahaan Hutan). Semenjak tahun 1980-an hingga kini, perkembangan ekspansi perkebunan sawit terus meluas ke berbagai daerah. Pengembang perkebunan juga berada di balik bencana kebakaran hutan tahun 1997/1998. Pembakaran hutan dinilai sebagai pilihan paling murah untuk membuka lahan hutan untuk membangun perkebunan berskala besar. Data dari Sawit Watch dan FPP, tahun 2006 saja pemerintah daerah telah menargetkan 20 miliar hektar lagi hingga tahun 2020 untuk perkebunan sawit (Down to Earth, 2011).

Sejumlah besar kawasan hutan dan lahan gambut menjadi target untuk pengembangan dalam rencana-rencana di Papua, Riau, Kalimantan, Aceh dan daerah- 
daerah lainnya. Satu skema perkebunan raksasa yang direncanakan di wilayah perbatasan Indonesia-Malaysia di Kalimantan Timur dan Kalimantan Barat meliputi 1,8 juta hektar lahan yang sebagian besarnya adalah kawasan hutan. Papua dan Aceh juga menjadi target untuk perluasan lebih lanjut (Down to Earth, 2011).

Perubahan peruntukan kawasan hutan melalui mekanisme revisi tata ruang selama masa moratorium cenderung meningkat. Pelepasan kawasan hutan melalui revisi tata ruang pun rawan ditunggangi kepentingan korporasi. Penggunaan skema revisi tata ruang menjadi modus korporasi untuk memperoleh lahan atau menghilangkan bukti perambahan hutan oleh mereka. Beberapa provinsi yang kemudian terbukti mengakomodasi kepentingan korporasi antara lain Bengkulu, Sumatera Selatan, Kalimantan Tengah, Maluku Utara dan Papua. Pelepasan kawasan hutan secara parsial juga terjadi melalui mekanisme permohonan langsung oleh korporasi. Sepanjang tahun 1987-2016 Kementerian Lingkungan Hidup dan Kehutanan telah memberikan izin pelepasan kawasan hutan untuk perkebunan sawit sebanyak 514 unit seluas 5.319.958 hektare tersebar di 23 provinsi. Provinsi Riau menjadi lokasi dengan konsesi sawit terbanyak dan terluas sebanyak 102 unit dengan luasan 1.103.218 hektare (Waluyo et al., 2017).

Tabel 1. Pelepasan Kawasan Hutan untuk Perkebunan Sawit tahun 1987-2016

\begin{tabular}{clll}
\hline No. & Provinsi & Unit & $\begin{array}{l}\text { Luas } \\
\text { (dalam ha). }\end{array}$ \\
\hline 1 & Aceh & 47 & 207.056 \\
2 & Sumatera Utara & 21 & 124.188 \\
3 & Riau & 102 & 1.103 .218 \\
4 & Sumatera Barat & 18 & 132.806 \\
5 & Jambi & 28 & 291.301 \\
6 & Bengkulu & 5 & 36.664 \\
7 & Riau Kepulauan & 4 & 34.363 \\
8 & Sumatera Selatan & 36 & 231.825 \\
9 & Lampung & 1 & 216 \\
10 & Kalimantan Barat & 25 & 276.085 \\
11 & Kalimantan Utara & 4 & 55.941 \\
12 & Kalimantan Timur & 32 & 316.039 \\
13 & Kalimantan Selatan & 15 & 181.054 \\
14 & Kalimantan Tengah & 93 & 928.426 \\
15 & Sulawesi Selatan & 1 & 602 \\
16 & Sulawesi Tengah & 5 & 60.307 \\
17 & Sulawesi Barat & 6 & 63.191 \\
18 & Gorontalo & 5 & 55.941 \\
19 & Sulawesi Utara & 2 & 7.862 \\
20 & Maluku Utara & 7 & 34.089 \\
21 & Maluku & 8 & 4.457 \\
22 & Papua & 30 & 785.902 \\
23 & Papua Barat & 20 & 365.504 \\
& Total Seluruh Indonesia & 514 & 5.319 .958 \\
\hline
\end{tabular}

Sumber: Kementerian Lingkungan Hidup dan Kehutanan (dalam Waluyo, 2017: 8).

Ekspansi sawit telah menimbulkan bencana serius bagi keanekaragaman hayati dan menjadikan bentang alam daerah tropis di Indonesia semakin rentan terhadap kebakaran hutan. Ekspansi sawit untuk memfasilitasi peningkatan ekspor telah berdampak serius pada 
intensitas konflik antara satwa dan penduduk sekitar perkebunan (Chris, 2018: 56). Riau, wilayah dengan konsesi sawit terbesar konflik satwa-manusia menghadapi kondisi yang serius. Berdasar data dari Balai Konservasi Sumber Daya Alam (BBKSDA) Riau pada tahun 2018 tercatat ada 35 konflik yang tersebar di seluruh kabupaten/kota. Konflik manusia dengan satwa paling banyak terjadi di Kabupaten Kampar. Ada 7 kasus yang tercatat, seperti konflik dengan Monyet Ekor Panjang (Macaca Fascicularis) dan Gajah Sumatra (Elephas Maximus Sumatranus) (Anonim, 2018).

Jumlah ini kemudian disusul oleh Kabupaten Bengkalis sebanyak 5 kasus, yakni beruang madu dan gajah sering muncul bahkan berkonflik dengan warga disana. Selanjutnya, di Kabupaten Pelalawan ada 4 kasus terdiri dari Harimau Sumatera, Buaya Muara, Beruang Madu dan Gajah Sumatera. Di Inhil terdapat 3 kasus diantaranya Harimau Sumatra, Buaya Muara, dan Beruang Madu. Bukan hanya di kabupaten saja, tetapi di Kota Pekanbaru juga ada konflik dengan satwa tercatat ada 2 yaitu dengan gajah. Terakhir ada di Kepulauan Meranti dan Kabupaten Indragiri Hulu (Inhu), masing-masing hanya 1 konflik (Anonim, 2018). Di Meranti dengan buaya muara, sedangkan di Inhu dengan harimau Sumatera. Kemudian disusul dengan Kabupaten Siak serta Kabupaten Kuantan Singingi (Kuansing), masing-masing ada 6 kasus.

Di Aceh pembukaan hutan primer berdasarkan penelusuran Wahana Riset Indonesia telah mendorong peningkatan intensitas konflik gajah-manusia. Konflik manusia dan gajah telah berlangsung cukup lama. Menurut Balai Konservasi Sumber Daya Alam (BKSDA) Aceh, sepanjang 2012-2017 tercatat 68 ekor gajah mati, 55 ekor (81\%) di antaranya diakibatkan oleh konflik dengan manusia. Konflik gajah yang terus meningkat dari tahun ke tahun di Aceh berdampak pada penurunan populasi gajah dari sekitar 800 ekor di tahun 2003, menjadi 500-535 ekor di tahun 2015 (Qomariah, 2018).

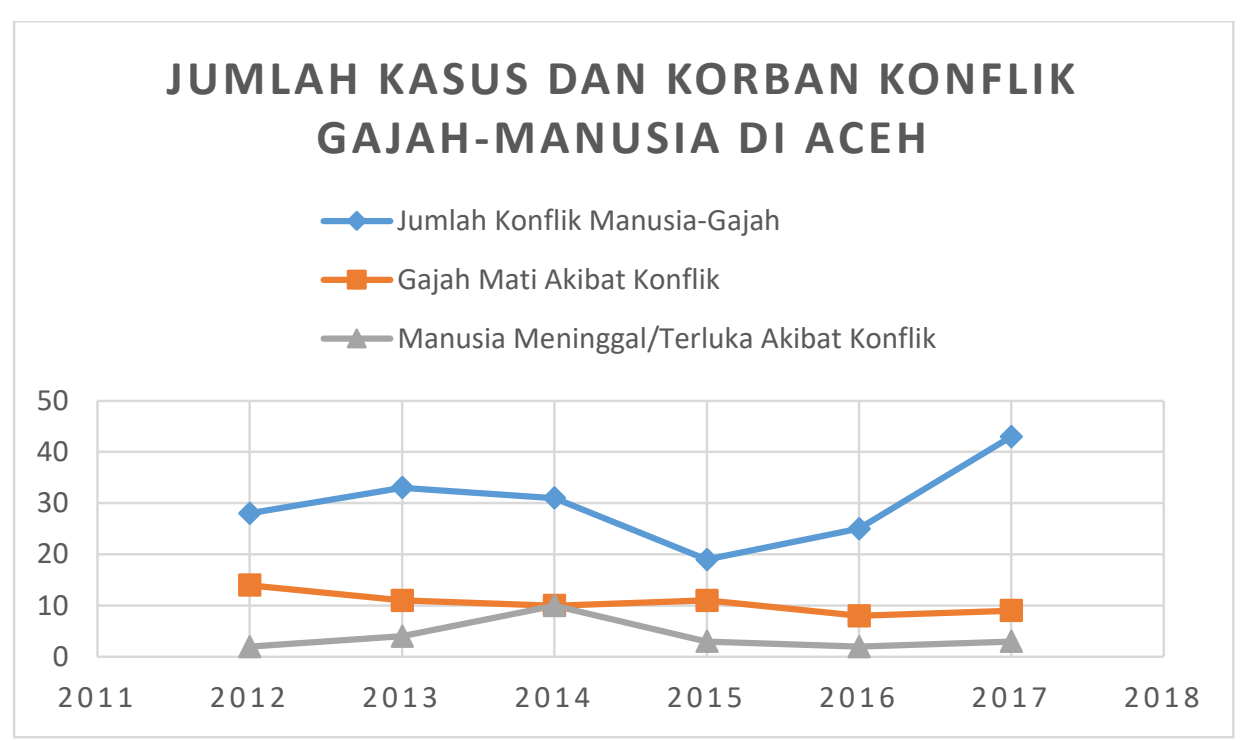

Grafik 1. Kasus konflik manusia dan gajah di Aceh tahun 2012-2017 (Sumber: Qomariah, 2018)

Di Papua konsesi perkebunan sawit terbesar berada di bawah kendali grup perusahaan Korindo yang mendorong pembukaan besar-besaran hutan primer. Temuan dari Mighty menunjukkan sejak 2013, perusahaan ini mempercepat pembukaan dan pembakaran lahan secara agresif untuk dijadikan perkebunan kelapa sawit dengan menghancurkan 30.000 hektar hutan dari awal 2013 hingga Mei 2016. Dari luasan itu, 11.700 hektar adalah hutan primer. Dalam lamannya, Korindo menyatakan target 200.000 hektar perkebunan kelapa 
sawit pada 2020. Korindo juga melakukan pembukaan hutan dengan cara pembakaran yang telah mengancam keberadaan kanguru pohon di ambang kepunahan (Bellantonio, Stoltz, Lapidus, Maitar, \& Hurowitz, 2016).

Riset yang dilakukan oleh Risal (2015) lebih jauh menemukan bahwa keberadaan perkebunan kelapa sawit juga mengancam kelangsungan hidup dari primata yang berasal dari hutan Kalimantan, khususnya Kalimantan Timur. Sebuah kasus yang terjadi pada tahun 2011 ditemukan tulang belulang orang utan (Pongo pymaeus mario) di hutan Kutai Kartanegara. Spesies langka ini merasa terpojok dengan ekspansi kebun sawit milik PT Khaleda Agroprima Malindo, anak perusahaan Metro Kajang Holding Bhd. Perusahaan memiliki izin untuk membuka lahan hutan seluas 16 ribu hektar untuk menjadi kebun sawit. Lahan tersebut menjadi habitat dari 200-an orang utan (Risal, 2015: 10-15).

Orang utan yang kehilangan habitatnya kemudian memakan pucuk-pucuk pohon sawit sebagai sumber makanan pengganti. PT Khaleda memperparah konflik satwa-manusia dengan melibatkan penduduk lokal dalam upaya memberantas orang utan yang dianggap sebagai "hama". Setiap ekor orang utan yang berhasil ditangkap dihargai dengan upah satu juta rupiah. Masuknya orang utan ke kawasan perkebunan milik perusahaan menunjukkan bahwa ada yang salah dalam hal pengelolaan dan sistem pengawasan pembukaan lahan perkebunan sawit yang mengganggu kehidupan dan ekosistem lingkungan yang menjadi habitatnya (Risal, 2015: 10-15).

Konflik antara orang utan dan industri sawit juga terjadi di Kabupaten Ketapang, Kalimantan Barat. Berdasarkan catatan ProFauna pada tahun 2011 tercatat ada 5 kasus konflik antara masyarakat dan orang utan. Orang utan dianggap hama disebabkan memakan buah sawit. Konfik dengan orang utan tersebut melibatkan beberapa perusahaan kelapa sawit. Di Kabupaten Ketapang dan sekitarnya sedikitnya ada 75 perusahaan kelapa sawit. Pada tahun 2010-2011 ditemukan kerangka orang utan di areal PT Limpah Sejahtera dan penangkapan bayi orang utan di PT Andes Sawit Lestari. Pada rentang tahun yang sama ditemukan 3 orang utan di areal land clearing PT Kayang Agro Lestari (ProFauna, 2013: $\underline{23}$.

Perkebunan sawit dalam skala industri untuk memfasilitas peningkatan ekspor telah menyebabkan satwa hanya mendapatkan habitat tersisa di kantung-kantung yang belum terdeforestasi. Beberapa perusahaan telah menyisakan beberapa areal lahannya untuk keperluan habitat hewan. Kantong-kantong habitat ini diklaim dapat memberikan ruang bagi spesies untuk tetap hidup dan berkembang biak. Beberapa perkebunan sawit di Kalimantan, misalnya PT Sukses Tani Nusasubur, PT Karyanusa Eka Daya, dan PT Agro Menara Rahmat sengaja mengembangkan program-program "konservasi" (Bandung Sahari, 2011).

Akan tetapi, satwa tetap rentan menghadapi pemusnahan akibat bersinggungan dengan ekonomi sawit. Terdegradasinya ekosistem di dalam kawasan perkebunan sawit menyebabkan wilayah ini tidak dapat berfungsi dengan baik sebagai habitat satwa liar, meskipun tingkat perjumpaan binatang cukup tinggi. Hal ini dapat menjadi ancaman terhadap penurunan populasi satwa liar di kawasan ini. Faktor-faktor ancaman seperti tingginya tingkat perburuan satwa dan perusakan habitat melalui penebangan tegakan menyebabkan kehidupan binatang semakin terancam (Arief, 2013: 79-80).

Tidak hanya rusaknya habitat, degradasi hutan untuk peruntukan ekspansi sawit telah menyebabkan fragmentasi tempat tinggal hewan liar. Satwa juga semakin terancam kehidupannya akibat meningkatnya intensitas perburuan pasca hutan dialihfungsikan untuk memfasilitasi ekspansi sawit. Hal ini memperparah kondisi dengan adanya koneksi perusakan hutan untuk peruntukan ekspansi sawit dengan pasar perdagangan ilegal hewan (Arief, Mijiarto, \& Rahman, 2015: 161-162). Satwa yang sudah berkurang jumlahnya 
dieksploitasi habis-habisan oleh manusia yang tidak bertanggung jawab dengan diperjualbelikan. Tingginya aktivitas manusia di dalam areal produksi dan sekitar badanbadan air yang mengakibatkan beberapa jenis fauna di dalamnya tidak dapat berperilaku alami, termasuk dalam upaya perkembangbiakannya. Fragmentasi habitat yang semakin meluas juga memperparah kondisi perkembangbiakan, sehingga jumlahnya semakin berkurang (Arief et al., 2015: 161-162).

Upaya penangkaran terhadap hewan-hewan liar berusaha dilakukan untuk mengurangi intensitas konflik satwa-manusia kenyataannya tak lebih dari mengusir satwa dari habitatnya, demi ekspansi sawit. Penangkaran juga menyebabkan kondisi hak hewan liar semakin tidak terpenuhi akibat manusia memandangnya sebagai sesuatu yang "eksotis." Pengelola penangkaran yang biasanya masih terkait dengan rantai industri sawit justru menjadikan hewan liar yang ditangkarkan sebagai "tontonan" untuk mendapatkan pundipundi rupiah lain (Learmonth, 2019: 5-7).

Hewan liar bahkan menjadi kehilangan karakter aslinya dan justru menjadi jinak serta hidupnya menjadi tergantung pada pemberian manusia. Hewan yang ditangkarkan akibat ekspansi sawit juga dapat kehilangan naluri alamnya akibat perbedaan secara kontras lingkungan penangkaran dengan habitatnya. Kehidupan alami yang menjadi bagian dari hak mendasar satwa liar untuk menopang peri kehidupannya menjadi tidak ada dalam penangkaran, sehingga kondisi satwa semakin rentan (Learmonth, 2019: 5-7).

Proses penangkaran hewan yang terdampak ekspansi sawit sendiri menunjukkan kemenangan sudut pandang antroposentrisme yang memperparah kerusakan lingkungan. Antroposentrisme menyebabkan hukum keseimbangan alam mudah diabaikan disebabkan oleh kurangnya kesadaran mengenai konsekuensi yang muncul bagi satwa dan warga. Dominasi manusia dari alam bermanifestasi sebagai kasus ekstrem, di mana hewan liar tidak memiliki suara dan prioritas manusia selalu menang (Paquet \& Darimont, 2010: 180-185). Meskipun ada hubungan yang tak terbantahkan di antara keduanya, degradasi ekologis yang disebabkan manusia dan tidak gangguan bagi kehidupan satwa liar. Penderitaan hewan liar sebagian besar menunjukkan implikasi negatif dari antroposentrisme.

Dominasi antroposentrisme dengan menonjolkan fasilitasi terhadap ekspansi sawit dibandingkan dengan menjaga habitat satwa liar di hutan dapat ditunjukkan dengan laju deforestasi untuk memfasilitasi industri CPO yang makin meluas. Industri kelapa sawit dan kertas telah menimbulkan deforestasi, terutama di Sumatera pada tahun 2014 kehilangan $55 \%$ tutupan hutannya dalam jangka waktu 29 tahun. Laju rata-rata pembukaan hutan sekitar 480.000 ha per tahun. Penandatanganan komitmen industri sawit untuk mencegah deforestasi, kenyataannya tidak mencegah proses pembukaan hutan yang terjadi (Eyes on the Forest, 2016b: 5-13).

Translokasi membawa kerentanan baik bagi individu maupun lingkungan komunitas hewan liar yang dipindahkan. Kerentanan terhadap kebutuhan habitat, perilaku predasi dan adaptasi pada situasi baru, sedangkan pada tingkat populasi binatang liar rentan menghadapi penurunan jumlah. Satwa juga dapat terluka atau bahkan mati dalam proses translokasi. Satwa yang sudah tercerabut dari habitatnya juga harus berjuang untuk mencari makan, tempat berlindung, dan tempat yang aman untuk membesarkan anaknya (Santosa \& Pairah, 2011: 156-157).

Perebutan kawasan habitat juga dapat terjadi akibat kontestasi antara satwa liar yang baru dipindahkan dengan binatang yang lebih dahulu menetap. Hal ini memperparah risiko pembunuhan anak dan agresi intraspesifik. Binatang liar yang tidak dapat beradaptasi juga rentan stres dan memiliki perilaku agresif berhubungan erat dengan kondisi individu hewan (Santosa \& Pairah, 2011: 156-157). Hewan juga bisa berubah agresif menyerang manusia 
kala di wilayah translokasi dibandingkan kala dipindahkan. Stres merupakan variabel penting yang mempengaruhi kelangsungan hidup satwa dalam program reintroduksi. Stres merupakan salah satu penyebab utama tingkat kematian yang tinggi selain predator.

Hal tersebut menunjukkan bahwa kebanyakan industri sawit kurang mempertimbangkan degradasi lingkungan yang muncul. Industri sawit berusaha melakukan upaya merasionalisasi penderitaan hewan liar yang dikorbankan untuk memenuhi kepentingan populasi manusia. Jelas, penderitaan hewan yang disebabkan manusia adalah masalah yang kontroversial dengan nuansa keagamaan dan moral yang cenderung diabaikan. Nilai-nilai agama dan moral manusia yang berusaha memenuhi kesejahteraan hewan realitasnya tidak pernah diperhatikan dalam perubahan wilayah hutan menjadi perkebunan sawit skala industri (Paquet \& Darimont, 2010: 80-85).

Pada dasarnya memang tidak semua masalah kesejahteraan hewan menjadi masalah konservasi. Akan tetapi, semua masalah konservasi mungkin menunjukkan bahwa ada masalah kesejahteraan hewan. Manajemen untuk menyinergikan konservasi dan animal welfare dalam menanggulangi konflik satwa-manusia akibat ekspansi sawit dapat dilakukan (Blumstein, 2010: 152-155). Langkah jangka pendek dan jangka panjang perlu dilakukan untuk memastikan bahwa satwa liar tidak menghadapi penderitaan yang bertubi-tubi akibat ekspansi sawit yang mengancam habitat mereka. Akan tetapi, langkah yang dirancang oleh pemerintah dan organisasi masyarakat peduli sayangnya tidak bisa saling dipertemukan. Organisasi masyarakat sipil pun masih terbelah dalam paradigma konservasi dan animal welfare secara terpisah dalam upaya mencegah adanya konflik satwa-manusia (Blumstein, 2010: 152-155).

\section{E. PENUTUP}

Kajian ini telah membuktikan bagaimana peran pemerintah dalam menjaga pola rezim pasar bebas yang menyebabkan ekspansi sawit secara masif. Namun, mengabaikan aspek perlindungan lingkungan terutama lingkungan hewan dilindungi, sehingga memperlihatkan keberpihakan negara yang meminggirkan aspek kesejahteraan hewan. Negara justru mengeluarkan kebijakan publik yang memfasilitasi ekspansi sawit untuk menopang ambisinya dalam meningkatkan ekspor CPO. Negara bahkan akan melakukan berbagai cara termasuk menyebut arahan Uni Eropa sebagai stigma terhadap ambisi ekspor CPO. Meskipun, ketakutan berlebihan dari pemerintah Indonesia mengenai pengurangan ekspor CPO ke Uni Eropa akan berkurang kenyataannya tidak terbukti akibat adanya efek substitusi, peningkatan konsumsi biodesel dalam negeri, dan peningkatan konsumsi minyak kelapa sawit untuk makanan dan kosmetik.

Kebijakan publik yang berkaitan dengan fasilitasi sawit mulai dari proses perizinan, moratorium sampai dengan sertifikasi lingkungan tidak pernah benar-benar memperhatikan keberadaan habitat dan peri kehidupan satwa liar. Kebijakan publik yang berlabel "konservasi" kenyataannya hanya sebatas slogan untuk terus memfasilitasi ekspansi perkebunan sawit untuk memastikan ambisi ekspor CPO yang terus meningkat. Rezim perizinan dan moratorium yang dikeluarkan oleh pemerintah justru memperparah proses deforestasi kawasan hutan, lahan gambut bahkan "lahan kritis" yang menyebabkan hilangnya habitat dan terancamnya kehidupan satwa liar termasuk hewan yang dilindungi. Sertifikasi lingkungan yang didorong untuk muncul tidak berkutik untuk memastikan pengelolaan sawit dilakukan secara berkelanjutan disebabkan oleh penggunaannya yang bersifat sukarela. Akibatnya demi ambisi peningkatan ekspor sawit, pengalihfungsian kawasan hutan untuk perkebunan sawit dalam skala industri terus difasilitasi dibandingkan dengan mempertimbangkan terjaganya keseimbangan alam. 
Rezim perizinan untuk memfasilitasi ekspansi perkebunan sawit telah terbukti mendorong tergerusnya habitat hewan liar dan memperburuk kehidupannya. Hewan liar harus bersinggungan dengan manusia menghadapi konflik serius yang menyebabkan terjadinya penyiksaan dan pembunuhan terhadap binatang. Ekspansi sawit menyebabkan habitat hewan hanya tersisa di kantung-kantung wilayah tertentu. Meskipun perusahaan sawit telah menyediakan alokasi ruang untuk habitat hewan liar, kenyataannya tidak benarbenar menyelesaikan konflik antara binatang dengan manusia. Penangkaran yang diklaim akan menyelamatkan hewan liar dari kondisi buruk dari ekspansi sawit kenyataannya justru berujung pada penaklukan kehidupan hewan yang tidak sesuai dengan naluri alamiahnya. Pemerintah dan perusahaan sawit dalam melakukan ekspansi perkebunan kurang memahami naluri alamiah hewan liar yang memiliki daya jelajah tertentu dan terikat dengan ruang hidupnya.

Untuk mengatasi peminggiran kehidupan hewan liar dalam fasilitasi ekonomi perkebunan sawit diperlukan sudut pandang lintas spesies dalam kebijakan publik. Kebijakan publik yang dimuat oleh pemerintah dalam fasilitasi sawit hendaknya dapat memahami habitat hewan dan naluri alamiahnya. Pemetaan terhadap daerah jelajah satwa liar bersama habitatnya diperlukan untuk menyelesaikan tumpang-tindih perkebunan sawit dengan daerah satwa. Perkebunan sawit yang tumpang-tindih dengan habitat hewan perlu ditindak dan dicabut izinnya, sehingga muncul jaminan dari negara terhadap peri kehidupan hewan. Dengan memahami daerah jelajah hewan, maka kemungkinan terjadinya konflik antara satwa dan manusia dapat dihindari karena kegiatan ekonomi sawit tidak akan merusak dan mengganggu peri kehidupan hewan.

\section{DAFTAR PUSTAKA}

Abdullah, S, M. A., \& Hilmayanti, P. (2017). Persepsi Masyarakat Sekitar Kawasan Konflik Gajah Dengan Manusia Terhadap Konservasi Gajah Dan Habitatnya Di Kecamatan Lembah Seulawah, Aceh Besar. Jurnal Biologi Edukasi, 9(1), 16-19.

Adi, H. (2019). Uni Eropa Tekan Sawit Indonesia, Luhut: Ini Masalah Kedaulatan Negara. Amelia, D. (2017). Penolakan Pemerintah Indonesia Terhadap Perubahan Tarif Pajak Cpo (Crude Palm Oil) Oleh Perancis 2016. Jom Fisip, 4(2), 1-11.

Andyono, G., Marsono, D., Sadono, R., \& Imron, M. A. (2018). The Analysis On The Stakeholders Of Conflict Mitigation In The Way Kambas National Park, Lampung. Kinerja, 22(1), 15-28.

Anonim. (2018). BBKSDA Catat Konflik Manusia dengan Satwa di Riau Capai 35 Kasus. Retrieved from https://www.halloriau.com/read-otonomi-107799-2018-11-21bbksda-catat-konflik-manusia-dengan-satwa-di-riau-capai-35-kasus.html

Apindo. (2017). Policy Brief Perbaikan Regulasi Lahan Gambut Dalam Mendukung Peran Sektor Industri Kelapa Sawit Indonesia. Jakarta.

Arief, H. (2011). Keanekaragaman Jenis Satwaliar Di Kawasan Perkebunan Kelapa Sawit dan Status Perlindungannya: Studi Kasus Kawasan Unit Pengelolaan Pt. Agrowiyana, Kabupaten Tanjung Jabung Barat, Jambi. Media Konservasi, 16(2), 73 $-77$.

Arief, H., Mijiarto, J., \& Rahman, A. (2015). Keanekaragaman dan Status Perlindungan Satwaliar Di Pt. Riau Sawitindo Abadi. Media Konservasi, 20(1), 159-165.

Bandung Sahari. (2011). Konservasi vs kelapa sawit: antara tudingan \& fakta. Retrieved from https://ekbis.sindonews.com/read/537018/36/konservasi-vs-kelapa-sawitantara-tudingan-fakta-1322797022 
Bellantonio, M., Stoltz, A., Lapidus, D., Maitar, B., \& Hurowitz, G. (2016). Surga yang Terbakar: Kelapa Sawit di Tanah Kanguru Pohon. Retrieved from http://www.mightyearth.org/BurningParadise-Bahasa/

Blumstein, D. (2010). Conservation and animal welfare issues arising from forestry practices. Animal Welfare, 19(1), 151-157.

Bonita, M. (2018). Strategi Indonesia Dalam Menanggapi Resolusi Parlemen Uni Eropa No. P8_Ta(2017)0098 Tentang Palm Oil And Deforestation Of Rainforest Tahun 2017. JOM FISIP, 5(2), 1-12.

Brakes, P. (2019). Sociality and Wild Animal Welfare: Future Directions. Frontiers in Veterinary Science, 62(6), 1-7.

Butler, R. A. (2008). Kenapa kelapa sawit menggantikan hutan hujan? Kenapa biofuels menggerakkan penggundulan hutan? Retrieved from https://world.mongabay.com/indonesian/sawit.html

Centre for Orangutan Protection. (2009). Enam Tahun RSPO. Orangufrem, 1, 3-5.

Chris. (2018). Pendorong Laju Deforestasi Dampak dari meningkatnya permintaan minyak sawit melalui kebijakan biofuel. Jakarta.

Dijk, K. van, \& Savenije, H. (2011). Kelapa sawit atau hutan? Lebih dari sekedar defnisi. Policy Brief Tropenbos International Indonesia Programme, 20(iv), 1-20.

Down to Earth. (2011). Seabad Perkebunan Kelapa Sawit di Indonesia. Retrieved from https://www.downtoearth-indonesia.org/id/story/seabad-perkebunan-kelapa-sawitdi-indonesia

Edi, J. (2019). Isu Lingkungan Hidup dan Prospek Ekspor Sawit Indonesia. Retrieved from https://kumparan.com/jepri-edi/isu-lingkungan-hidup-dan-prospek-ekspor-sawitindonesia-1qkkTjdZB9T

Erman, E. (2017). Di Balik Keberlanjutan Sawit: Aktor, Aliansi Dalam Ekonomi Politik Sertifikasi Uni Eropa. Masyarakat Indonesia, 43(1), 1-13.

Eyes on the Forest. (2016). Tak ada yang aman Kelapa sawit ilegal menyebar melalui rantai pasokan dunia kendati ada komitmen dan sertifikasi kelestarian global. Jakarta.

Fetra, T., Apriliana, M., \& Putra, A. (2019). Menakar Keberpihakan Wakil Rakyat pada Isu Lingkungan Rancangan Undang-Undang Perkelapasawitan (M. T. Surya, Ed.). Jakarta: Yayasan Madani Berkelanjutan.

Forest Watch Indonesia. (2016). Factssheet Roadmap Masyarakat Sipil Untuk Reforma Perkebunan Sawit Indonesia Berkeadilan. Jakarta.

Fredriksson, G. (2005). Human-sun Bear Conflicts In East Kalimantan, Indonesian Borneo. Ursus, 16(1), 130-137.

Greenpeace. (2013). Izin Memusnahkan: Bagaimana deforestasi dariperkebunan kelapa sawit mendorong harimau Sumatra menuju kepunahan (Greenpeace, Ed.). Jakarta: Greenpeace International.

Gunawan, H., Iskandar, S., Sihombing, V. S., \& Wienanto, R. (2017). Conflict between humans and leopards (Panthera pardus melas Cuvier, 1809) in Western Java, Indonesia. Biodiversitas, 18(2), 652-658.

Hutchins, M., \& Wemme, C. (1987). Wildlife Conservation And Animal Rights: Are They Compatible? Animal Welfare Science, 111-137.

Indrapraja, F. M. (2018). Analisis Terhadap Sertifikasi Minyak Kelapa Sawit Berkelanjutan Sebagai Instrumen Penaatan Hukum Lingkungan. Jurnal Hukum Lingkungan, 4(2), $\underline{48-76 .}$

Jordan, B. (2005). Science-based assessment of animal welfare: wild and captive animals. Rev. Sci. Tech. Off. Int. Epiz, 24(2), 515-528. 
Kamim, A. B. M. (2018). Perebutan Ruang Kehidupan dan Gangguan terhadap Animal Rights Studi Atas Konflik Satwa-Manusia sebagai Implikasi dari Ekspansi Perkebunan Sawit di Indonesia. BALAIRUNG: Jurnal Multidisipliner Mahasiswa Indonesia, 1(2), 199-217.

Kunjana, L. G. (2019). Menko Luhut: Negara Pasang Badan untuk Petani Sawit. Retrieved from https://www.beritasatu.com/ekonomi/545442-menko-luhut-negara-pasangbadan-untuk-petani-sawit

Learmonth, M. J. (2019). Dilemmas for Natural Living Concepts of Zoo Animal Welfare. Animals, 318(9), 1-13.

Lubis, F. D. W., Afifuddin, Y., \& Patana, P. (2014). Mitigasi Konflik Orangutan Sumatera (Pongo Abelii) Dengan Masyarakat Di Sekitar Taman Nasional Gunung Leuser. Peronema Forestry Science Journal, 3(2), 1-11.

MADDEN, F. M. (2008). The Growing Conflict Between Humans and Wildlife: Law and Policy as Contributing and Mitigating Factors. Journal of International Wildlife Law \& Policy, 11, 189-206.

Malins, C. (2017). For Peat's Sake Memahami Dampak Konsumsi Biodiesel Minyak Sawit Terhadap Iklim. Jakarta.

Mohammad, Y. (2018). Luhut Pandjaitan, Vatikan, dan sawit. Retrieved from https://beritagar.id/artikel/berita/luhut-pandjaitan-vatikan-dan-sawit

Nirmala, R. (2019). Luhut tak ingin dunia dikte sawit Indonesia. Retrieved from https://beritagar.id/artikel/berita/luhut-tak-ingin-dunia-dikte-sawit-indonesia

Nurfatriani, F., Ramawati, Sari, G. K., \& Komarudin, H. (2018a). Optimalisasi Dana Sawit Dan Pengaturan Instrumen Fiskal Penggunaan Lahan Hutan Untuk Perkebunan Dalam Upaya Mengurangi Deforestasi. Working Paper 238, 238, 1-58.

Nurfatriani, F., Ramawati, Sari, G. K., \& Komarudin, H. (2018b). Optimalisasi Dana Sawit Optimalisasi Dana Sawit dalam Mendorong Praktik- Praktik Perkebunan Kelapa Sawit Rakyat yang Berkelanjutan dalam Mendorong Praktik-praktik Perkebunan Kelapa Sawit Rakyat yang Berkelanjutan. Policy Brief, 12(2), 1-5.

Pablo, S., \& Arvirianty, A. (2019). Benarkah Sawit Indonesia Merusak Lingkungan?. Retrieved from https://www.cnbcindonesia.com/market/20190327132408-1763185/benarkah-sawit-indonesia-merusak-lingkungan

Paquet, P., \& Darimont, C. (2010). Wildlife conservation and animal welfare: two sides of the same coin? Animal Welfare, 19(2), 177-190.

Permatasari, A. P., Surya, T., Indarto, G. B., Aji, A. S., Fatimah, I., Minangsari, M., \& Mezariani, K. (2018). Lembar Fakta: 'Larangan' Impor Minyak Sawit Indonesia oleh Uni Eropa. Jakarta.

Prayudhi, R. T. (2015). Penegakan Hukum, Rehabilitasi Dan Pelepasliaran Satwa Dilindungi Hasil Sitaan Negara Ujung Tombak Upaya Penstabilan Ekosistem Kawasan Konservasi. Retrieved from https://www.researchgate.net/publication/307953979_PENEGAKAN_HUKUM_R EHABILITASI_DAN_PELEPASLIARAN_SATWA_DILINDUNGI_HASIL_SIT AAN_NEGARA_UJUNG_TOMBAK_UPAYA_PENSTABILAN_EKOSISTEM KAWASAN_KONSERVASI

ProFauna. (2013). Edukasi di Ketapang Kalimantan Barat untuk Mengurangi Konflik Orangutan dan Sawit. Suara Satwa, 17(1), 2-3.

Purnomo, H., Okarda, B., Dermawan, A., Ilham, Q. P., \& Bizarani, B. (2017). Proyeksi Sawit Indonesia: Debat kebijakan ekonomi, deforestasi dan moratorium. Diskusi Dan 
Konferensi Pers "Sawit: Penyebab Atau Penyelamat Deforestasi" Yang Diselenggarakan Oleh Thamrin School Climate Change and Sustainability, 1-37.

Qomariah, I. N. (2018). Konflik Manusia dan Gajah: Dampak Hilangnya Hutan yang Tak Terlihat. Retrieved from https://wri-indonesia.org/id/blog/konflik-manusia-dangajah-dampak-hilangnya-hutan-yang-tak-terlihat

Qomariah, I. N., Rahmi, T., Said, Z., \& Wijaya, A. (2019). Conflict Between Human And Wild Sumatran Elephant (Elephas Maximus Sumatranus Temminck, 1847) in Aceh Province, Indonesia. Biodiversitas, 20(1), 77-84.

Rianti, A., \& R.Garsetiasih. (2017). Persepsi Masyarakat Terhadap Gangguan Gajah Sumatera (Elephas maximus sumatranus) DI KABUPATEN OGAN KOMERING ILIR. Jurnal Penelitian Sosial Dan Ekonomi Kehutanan, 14(2), 83-99.

Risal, M. (2015). Multinational Corporations (MNC) Perkebunan Kelapa Sawit Di Kalimantan Timur: Dampak Aspek Lingkungan, Sosial Budaya, dan Ekonomi. Jurnal Interdependence, 3(1), 1-14.

S.Utami, S. P. (2019). Pemerintah siap boikot produk Eropa bila diskriminatif terhadap sawit. Retrieved from https://nasional.kontan.co.id/news/pemerintah-siap-boikotproduk-eropa-bila-diskriminatif-terhadap-sawit

Sally, N. U. (2016). Sengketa Minyak Sawit Antara Indonesia dan Uni Eropa. Jakarta.

Santosa, Y., \& Pairah. (2011). Permasalahan dan Manfaat Program Relokasi Satwa Liar. Pengembangan Perkebunan Kelapa Sawit Versus Konservasi Hidupan Liar Indonesia: Menciptakan Sinergi Kepentingan Ekonomi Dan Ekologi Dalam Pengelolaan Yang Berkelanjutan, 154-159.

Sawit Watch. (2019). Shadow Report: Kemana Arah Implementasi Inpres No. 8 Tahun 2018 (Moratorium Sawit) Berjalan? Jakarta.

Sidik, R. M. (2018). CPO Indonesia ditolak Uni Eropa, Kenapa?. Retrieved from https://igj.or.id/cpo-indonesia-ditolak-uni-eropa-kenapa/

Soedomo, S., Kartodihardjo, H., Hendrayanto, Wibowo, A. B., Adinugraha, A. G., Hadijah, S., ... Prasetyo, A. R. (2018). Tata Kelola Perkebunan Sawit Di Indonesia Studi Kasus di Provinsi Riau dan Kalimantan Barat (A. G. Adinugraha, S. Hadijah, \& F. R. Siahaan, Eds.). Bogor: Forci Development.

Suba, R. B., Ploeg, J. van der, Zelfde, M. van't, Lau, Y. W., Wissingh, T. F., Kustiawan, W., Iongh, H. H. de. (2017). Rapid Expansion of Oil Palm Is Leading to Human-Elephant Conflicts in North Kalimantan Province of Indonesia. Tropical Conservation Science, 10, 1-12.

Thomas, V. F. (2019). Pertanyakan Kritik ke Industri Sawit, Luhut: Salahnya Dimana?. Retrieved from https://tirto.id/pertanyakan-kritik-ke-industri-sawit-luhut-salahnyadimana-dkon

Waluyo, J., Berliani, H., Suhadi, Z., Surambo, A., Sutrisno, E., Fitra, S., \& Prameswari, A. (2017). Urgensi Kebijakan Moratorium Perkebunan Kelapa Sawit di Indonesia. Jakarta.

Widyastuti, R. A. Y. (2019). Dubes Uni Eropa Tegaskan Tak Ada Larangan Impor Sawit dari RI. Retrieved from https://bisnis.tempo.co/read/1282953/dubes-uni-eropategaskan-tak-ada-larangan-impor-sawit-dari-ri

Yasmin, P. A. (2019). Luhut: Ada 20 Juta Orang Hidup dari Sawit. Retrieved from https://finance.detik.com/berita-ekonomi-bisnis/d-4485720/luhut-ada-20-jutaorang-hidup-dari-sawit 